\title{
Pengaruh Efisiensi Manajemen Modal Kerja Terhadap Kinerja Operasi Perusahaan (Studi Pada Indexperusahaan Manufaktur Bursa Efek Indonesia) \\ Al Akzan ${ }^{1}$ \\ Buyung Sarita ${ }^{2}$ \\ Riskiamalia $\mathrm{Madi}^{3}$ \\ Program Sarjana, Universitas Halu Oleo, Kendari \\ Universitas Halu Oleo, Kendari \\ Email: alakzan115@gmail.com
}

\begin{abstract}
Abstrak. Penelitian ini bertujuan untuk mengkaji secara empiris faktor-faktor yang mempengaruhi efisiensi manajemen modal kerja terhadap kinerja operasi perusahaan. Penelitian ini diuji dengan lima variabel independen yaitu cash conversion cycle (CCC)), current ratio(CR), Net Working Capital Ratio (NWCR), Current Assets Turnover (CAT), Inventory Turnover dan satu variabel dependen yaitu Earning Before Interest Tax(EBIT).

Objek pada pada penelitian ini adalah perusahaan manufaktur yang terdaftar di Bursa Efek Indonesia, dengan menggunakan teknik Purposive sampling. Penulis memilih dua puluh enam perusahaan sebagai sampel. Teknik analisis yang digunakan adalah analisis regresi linier berganda dan uji hipotesis dan juga dilakukan uji asumsi klasik yang terdiri dari uji normalitas, uji multikolineritas, uji heterokedastisitas, uji autokerasi

Hasil penelitian ini menemukan bahwa variabel cash conversion cycle $(C C C)$ ) berpengaruh positif dan signifikan terhadap dan Earning Before Interest Tax(EBIT), current ratio(CR) berpengaruh positif signifikan terhadap Earning Before Interest Tax(EBIT), Net Working Capital Ratio (NWCR) berpengaruh positif dan tidak signifikan terhadap Earning Before Interest Tax(EBIT), Current Assets Turnover (CAT) berpengaruh negative signifikan terhadap Earning Before Interest Tax(EBIT), dan Inventory Turnover berpengaruh positif signifikan terhadap Earning Before Interest Tax(EBIT).
\end{abstract}

Kata Kunci : Harga Saham, Debt To Equity Ratio, Return On Asset, Return On Equity, Earning Per Share, Market Value Added, Suku Bunga, Kurs.

\section{PENDAHULUAN}

Perkembangan dunia usaha diera globalisasi menyebabkan semakin ketatnya persaingan antar perusahaan yang terdapat pada Bursa Efek Indonesia, oleh sebab itu setiap perusahaan dituntut untuk semakin efisien dalam menjalankan aktivitasnya serta memiliki strategi yang tepat agar mampu mempertahankan kinerja perusahannya, sebuah perusahaan dikatakan memiliki kinerja yang baik bisa dilihat melalui laporan keuangan perusahaan, menurut Wibisono (1997) Laporan keuangan perusahaan merupakan sumber data atau informasi yang menyajikan posisi kekayaan serta laba perusahaan (yang bersifat intern) secara priodik (berupa neraca dan laporan perhitungan rugi-laba). Apabila dari tahun ke tahun laporan keuangan perusahaan tersebut menunjukkan keuntungan yang semakin meningkat, berarti perusahaan tersebut memiliki kinerja yang baik. Hal ini menunjukkan bahwa meningkatnya kinerja perusahaan tidak lepas dari peran manajer keuangan melalui pengelolaan dan penggunaan modal kerja seefisien mungkin

Efisiensi Modal Kerja dilakukan oleh perusahaan agar modal kerja yang tersedia tidak kelebihan dan tidak juga kekurangan,hal ini disebabkan karena manajemen modal kerja berpengaruh secara langsung pada likuiditas dan profitabilitas perusahaan. Menurut (Deloof, 2003) efisiensi dalam manajemen modal kerja memerlukan pemahaman yang jelas tentang ekonomi trade-off yang terlibat di dalamnya,Oleh karena itu perusahaan mencoba untuk menjaga tingkat optimal dari modal kerja yang memaksimalkan nilai mereka.

Selain itu Modal kerja dalam perusahaan perlu ditelaah karena modal kerja penting bagi setiap perusahaan. Hal ini dikarenakan beberapa alasan seperti yang dikemukakan oleh Weston dan Brigham (1998) yaitu (1) Tanpa modal kerja perusahaan tidak dapat melakukan kegiatan opersional sehari-hari. (2) Sebagian besar waktu dari manajer dicurahkan untuk mengelola modal kerja 
perusahaan. (3)Aktiva lancar dari perusahaan manufaktur maupun perusahaan jasa memiliki jumlah yang cukup besar dari total aktiva perusahaan.

Manajemen modal kerja akan berpengaruh pada kinerja operasional perusahaan, kinerja operasional ini akan berpengaruh pada pendapatan yang akan diperoleh perusahaan, dalam hal ini yaitu kemampuan perusahaan untuk menghasilkan profitabilitas.Perusahaan yang dikatakan memiliki tingkat profitabilitas tinggi berarti tinggi pula efisiensi penggunaan modal kerja yang digunakan perusahaan tersebut.

Beberapa penelitian sebelumnya telah dilakukan terkait penelitian ini yaitu Syeh Ahsan Jamil( 2015) menguji pengaruh efisiensi manajemen modal kerja terhadap kinerja operasi perusahaan industri dioman periode tahun 2009-2013, temuan penelitian dari hasil analisis regresi semua sektor yaitu (1) working capital berpengaruh positive atau signifikan pada Net operating profit, sedangkan current assets dan cash from operating berpengaruh negative signifkan signifikan pada Net Operating profit, (2) working capital berpengaruh positive atau signifikan pada Earnings before interest and tax, sedangkan Cash from operating activities dan Current assets berpengaruh Negative signifikan pada Earnings before interest and tax. Sen dan Oruc (2009) menentukan hubungan antara tingkat efisiensi perusahaan yang diperdagangkan di Bursa Efek Istanbul dalam manajemen modal kerja dan profitabilitas yang diukur dengan ROA. Menurut hasil dalam hal semua perusahaan yang terlibat dalam studi dan sektor ada hubungan negatif yang signifikan antara $C C C$, tingkat modal kerja bersih, Current ratio, periode piutang, periode persediaan dan ROA. Akoto et al. (2013) menguji hubungan antara praktik manajemen WC dan profitabilitas dari semua 13 perusahaan manufaktur yang terdaftar di Ghana untuk periode 2005 hingga 2009. Penelitian ini menggunakan ROE sebagai proksi untuk profitabilitas. Hasil menunjukkan bahwa ada hubungan negatif yang signifikan antara profitabilitas dan hari piutang. Namun, CCC perusahaan, rasio aset saat ini, ukuran, dan perputaran aset lancar secara signifikan mempengaruhi profitabilitas

Raheman et al. (2010) menganalisis dampak manajemen working capital pada kinerja perusahaan di 204 perusahaan manufaktur Pakistan yang terdaftar di Bursa Efek Karachi untuk periode 1998-2007. Hasil menunjukkan bahwa CCC, siklus perdagangan bersih dan perputaran persediaan dalam beberapa hari secara signifikan mempengaruhi kinerja perusahaan. Leverage keuangan, pertumbuhan penjualan, dan ukuran perusahaan juga memiliki pengaruh signifikan terhadap profitabilitas perusahaan. Napompech (2012) meneliti efek manajemen working capital pada profitabilitas. Analisis regresi didasarkan pada sampel panel dari 255 perusahaan yang terdaftar di Bursa Efek Thailand untuk periode 2007-2009. Hasilnya menunjukkan hubungan negatif antara laba operasi bruto dan periode konversi inventaris dan periode penagihan piutang. Hasil penelitian juga menunjukkan bahwa karakteristik industri berdampak pada laba operasi bruto. Kaur dan Singh (2013) menganalisis kinerja WC dari 164 perusahaan manufaktur India BSE 200 yang diklasifikasikan ke dalam 19 industri selama periode 2000-2010. Model penelitian ini meliputi variabel independen, yaitu; efisiensi konversi tunai, hari siklus operasi dan hari working capital. Variabel dependen adalah profitabilitas yang diukur dengan pendapatan terhadap aset lancar dan pendapatan terhadap rata-rata total aset. Hasil menunjukkan bahwa manajemen Working Capital yang efisien secara signifikan mempengaruhi profitabilitas

Berdasarkan penelitian terdahulu diatas, jika dilihat secara umum bahwa terdapat beberapa perbedaan hasil . Maka dari itu peneliti tertarik untuk membuktikan dan meniliti ulang terkait pengaruh efisiensi manajemen modal kerja terhagadap kinerja perusahaan yang mana dalam penelitian ini objek yang diambil adalah perusahaan yang terdaftar pada adalah perusahaan manufaktur yang terdaftar pada Bursa Efek Indonesia periode 2016-2018.

\subsection{Trade Off Theory}

\section{KAJIAN PUSTAKA}

Trade off theory adalah teori struktur modal yang menyatakan bahwa perusahaan menukar manfaat pajak dari pendanaan utang dengan masalah yang ditimbulkan oleh potensi kebangkrutan. Dari model ini dapat dinyatakan bahwa perusahaan yang tidak menggunakan pinjaman sama sekali dan perusahaan yang menggunakan pembiayaan investasinya dengan pinjaman seluruhnya adalah buruk. 
Keputusan terbaik adalah keputusan yang moderat dengan mempertimbangkan kedua instrumen pembiayaan.

Trade off theory berasumsi bahwa adanya manfaat pajak akibat penggunaan utang, sehingga perusahaan akan menggunakan utang sampai tingkat tertentu untuk memaksimalkan nilai perusahaan. Esensi trade off theory dalam struktur modal adalah menyeimbangkan manfaat dan pengorbanan yang timbul sebagai akibat penggunaan utang. Sejauh manfaat lebih besar, tambahan utang masih diperkenankan. Apabila pengorbanan karena penggunaan utang sudah lebih besar, maka tambahan utang sudah tidak diperbolehkan. Penggunaan utang $100 \%$ sulit dijumpai dalam praktik dan hal tersebut ditentang oleh trade off theory. Kenyataannya, semakin banyak utang, semakin tinggi beban yang harus ditanggung perusahaan, seperti biaya kebangkrutan, biaya keagenan, beban bunga yang semakin besar dan sebagainya. Trade off theory telah mempertimbangkan berbagai faktor seperti corporate tax, biaya kebangkrutan, dan personal tax dalam menjelaskan mengapa suatu perusahaan memilih suatu struktur modal tertentu (Husnan, 2000).

\subsection{Kinerja Perusahaan}

Kinerja perusahaan adalah pengukuran prestasi perusahaan yang ditimbulkan sebagai akibat dari proses pengambilan keputusan manajemen yang kompleks dan sulit. Hal ini disebabkan dalam pengukuran prestasi perusahaan menyangkut efektivitas pemanfaatan modal, efisiensi, dan rentabilitas dari kegiatan perusahaan (Meriewaty dan Setyani 2005).

Menurut Munawir (2014), pengukuran kinerja keuangan memiliki beberapa tujuan, yaitu :

1 Untuk mengetahui tingkat likuiditas, yaitu kemampuan perusahaan untuk memenuhi kewajiban keuangan pada saat di tagih.

2 Untuk mengetahui tingkat solvabilitas, yaitu menunjukkan kemampuan perusahaan untuk memenuhi kewajiban keuangannya apabila perusahaan tersebut dilikuidasi, yang mencakup baik kewajiban jangka pendek ataupun jangka panjang.

3 Untuk mengetahui tingkat profitabilitas, yaitu menunjukkan kemampuan perusahaan untuk mendapatkan laba selama periode tertentu. Tujuan lainnya untuk mengetahui kemampuan stabilitas, yaitu kemampuan perusahaan untuk melakukan usahanya dengan stabil, yang diukur dengan mempertimbangkan kemampuan perusahaan untuk membayar cicilan secra teratur kepada pemegang saham tanpa mengalami hambatan.

Dengan begitu maka kinerja operasional ini akan berpengaruh pada pendapatan yang akan diperoleh perusahaan, dalam hal ini yaitu kemampuan perusahaan untuk menghasilkan profitabilitas.Perusahaan yang dikatakan memiliki tingkat profitabilitas tinggi berarti tinggi pula efisiensi penggunaan modal kerja yang digunakan perusahaan tersebut.

\subsection{Profitabilitas}

Profitabilitas adalah rasio yang menunjukkan keberhasilan perusahaan di dalam menghasilkan keuntungan (Robert Ang, 1997:18). Selain itu, profitabilitas adalah rasio yang mengukur efektifitas manajemen yang ditunjukkan oleh laba yang dihasilkan dari penjualan investasi perusahaan (J. Fred \& Thomas. E. Copeland, 2007).

Rasio profitabilitas memiliki tujuan tidak hanya bagi pemilik usaha atau manajemen saja, tetapi juga bagi pihak di luar perusahaan, terutama pihak-pihak yang memiliki hubungan atau kepentingan dengan perusahaan. Menurut Kasmir (2012), tujuan penggunaan rasio profitabilitas bagi perusahaan, maupun bagi pihak luar perusahaan, yaitu:

1. Untuk mengukur atau menghitung laba yang diperoleh perusahaan dalam satu periode tertentu.

2. Untuk menilai posisi laba perusahaan tahun sebelumnya dengan tahun sekarang.

3. Untuk menilai perkembangan laba dari waktu ke waktu.

4. Untuk menilai besarnya laba bersih sesudah pajak dengan modal sendiri.

5. Untuk mengukur produktivitas seluruh dana perusahaan yang digunakan baik modal pinjaman maupun modal sendiri.

Profitabilitas dapat diukur dengan menggunakan beberapa rasio. Rasio-rasio tersebut digunakan untuk mengukur dan mengevaluasi pendapatan sebuah perusahaan atas hubungannya dengan tingkat penjualan, aktiva, investasi, dan nilai saham 


\subsection{Manjemen Modal Kerja}

Modal kerja merupakan salah satu unsur aktiva yang sangat penting dalam perusahaan karena tanpa modal kerja perusahaan tidak dapat memenuhi kebutuhan dana untuk menjalankan aktivitasnya. Menurut J. Fred Weston Eugene F. Brigham (1991) dalam Yudhistira (2008), menyatakan bahwa Modal kerja adalah investasi perusahaan dalam harta jangka pendek yaitu kas, surat berharga jangka pendek, piutang dan persediaan.

Periode perputaran modal kerja (working capital turnover period) dimulai dari saat dimana kas diinvestasikan dalam komponen-komponen modal kerja sampai saat dimana kembali lagi menjadi kas. Semakin pendek periode tersebut berarti makin cepat perputarannya atau semakin tinggi tingkat perputarannya (turnover rate-nya). Jadi, semakin cepat tingkat perputaran masing-masing elemen modal kerja, maka modal kerja dapat dikatakan efisien. Namun, jika perputarannya semakin lambat, maka penggunaan modal kerja dalam perusahaan kurang efisien.

Perusahaan yang menghadapi kondisi ketika penjualan dan arus kas yang dihasilkan tidak pasti, dan situasi dapat berubah, maka perusahaan perlu menyiapkan cadangan kas yang cukup untuk memenuhi kebutuhan perusahaan. Semakin besar penyimpangan profitabilitas distribusi arus kas bersih yang mungkin terjadi maka semakin besar margin keamanan yang harus dimiliki oleh pihak manajemen (Van Horne dan Wachowicz, 2009).

\section{Kerangka Konsep Penelitian}

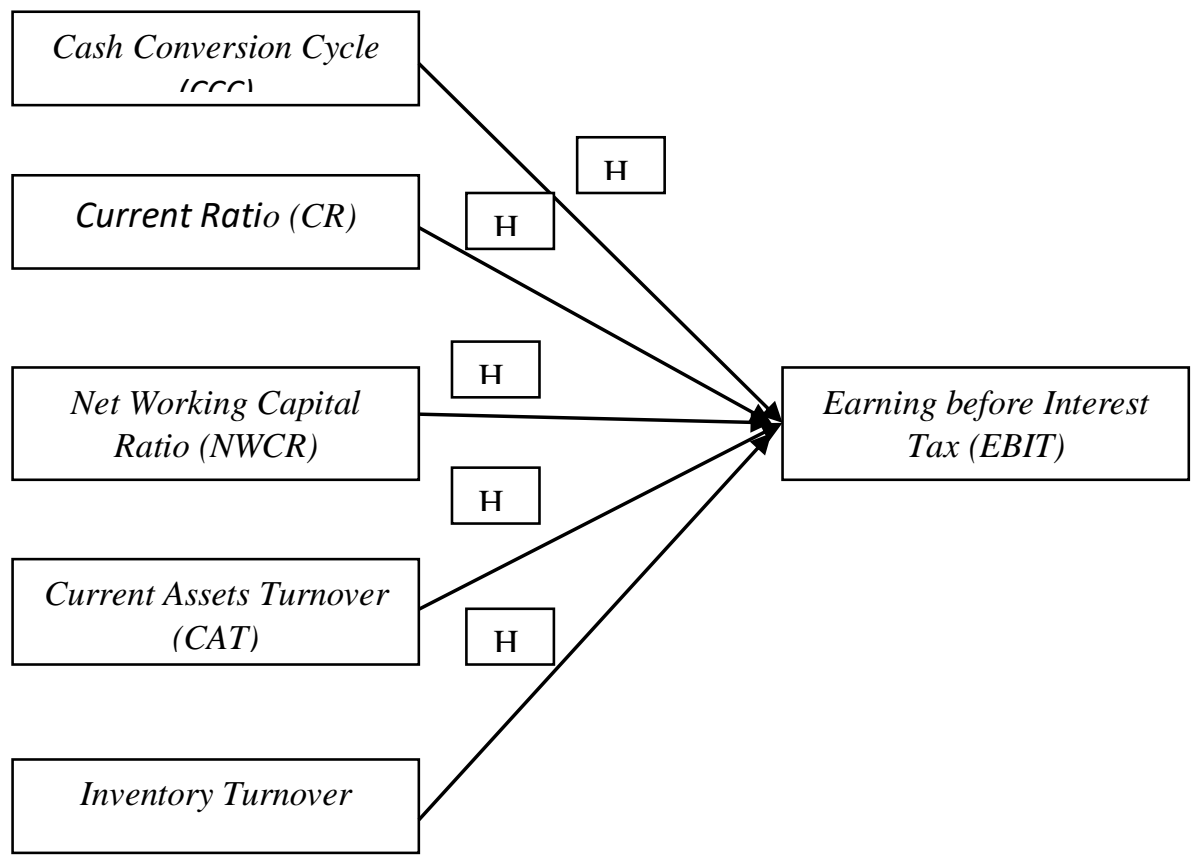

Berdasarkan kerangka konseptual diatas, maka dapat dirumuskan hipotesis penelitian sebagai berikut :

$\mathrm{H}_{1}$ : Cash Conversion Cycle (CCC) berpengaruh positif signifikan terhadap Earning before interest tax (EBIT

$\mathrm{H}_{2}$ : Current Ratio (CR) berpengaruh positif signifikan terhadap earning before interest tax (EBIT)

$\mathrm{H}_{3}$ : Net Working Capital Ratio (NWCR) berpengaruh positif signifikan terhadap earning before interest tax (EBIT) 
$\mathrm{H}_{4}$ : Current assets turnover (CAT) berpengaruh positif signifikan terhadap earning before interest tax (EBIT)

$\mathrm{H}_{5}$ : Inventory Turnover berpengaruh positif signifikan terhadap earning before interest tax (EBIT)

\subsection{Populasi dan Sampel}

\section{METODE PENELITIAN}

\subsubsection{Populasi}

Populasi adalah wilayah generalisasi yang terdiri atas obyek atau subyek yang mempunyai kualitas dan karakteristik tertentu yang ditetapkan oleh peneliti untuk dipelajari dan kemudian ditarik kesimpulannya (Sugiono : 2012). populasi dalam penelitian ini adalah seluruh perusahaan

Manufaktur yang terdaftar pada Bursa Efek Indonesia selama periode 2016-2018.

\subsubsection{Sampel}

Sampel merupakan sebagian atau wakil populasi yang diteliti (Arikunto : 2002). Metode pengambilan sampel yang digunakan dalam penelitian ini purposive sumpling. Metode purposive merupakan metode pengambilan sampel dimana peneliti memiliki kriteria atau tujuan tertentu terhadap sampel yang akan diteliti (Indriantoro, 1999). Proses pemilihan sampel yang ditempuh dalam penelitian ini disajikan yaitu :

1. Seluruh perusahaan manufaktur yang telah Go public yang terdaftar di bursa efek indonesia periode 2016-2018.

2. Perusahaan manufaktur yang menyediakan laporan keuangan dan rasio secara lengkap di bursa efek indonesia selama periode 2016-2018 sebanyak 26 perusahaan.

Berdasarkan kriteria sampel yang telah ditentukan maka sampel digunakan dalam penelitian ini berjumalah 26 Perusahaan.

\subsection{Teknik Analisis Data}

Teknik analisis data yang digunakan dalam penelitian ini adalah menggunakan regresi data panel dengan bantuan program Eviews 9, regresi data panel merupakan teknik regresi yang menggabungkan data time series dengan cross section. Widarjono (2013) mengatakan bahwa metode regresi data panel mempunyai beberapa keuntungan jika dibandingkan dengan data time series atau cross section. Pertama, data panel yang merupakan gabungan dua data time series dan cross section mampu menyediakan data yang lebih banyak sehingga akan menghasilkan degree of freedom yang lebih besar.

\subsection{Hasil Penelitian}

\section{HASIL DAN PEMBAHASAN}

\subsubsection{Hasil Pengeujian Hipotesis}

Penelitian ini menggunakan pengujian hipotesis secara parsial (Uji t) dan tidak menggunakan pengujian hipotesis secara simultan (Uji F). Uji t digunakan untuk mebuktikan pengaruh secara parsial variabel bebas terhadap variabel terikat.

\subsubsection{Uji t (Uji Parsial)}

Uji statistik t digunakan untuk mengukur seberapa jauh pengaruh masing-masing variabel bebas (X) dalam menerangkan variabel terikat (Y). 
Dependent Variable: $\mathrm{Y}$

Method: Panel EGLS (Cross-section weights)

Date: 08/16/20 Time: 20:32

Sample: 20162018

Periods included: 3

Cross-sections included: 26

Total panel (balanced) observations: 78

Linear estimation after one-step weighting matrix

\begin{tabular}{crrrr}
\hline \hline Variable & Coefficient & Std. Error & t-Statistic & Prob. \\
\hline \hline C & -2572.655 & 8801.545 & -0.292296 & 0.7713 \\
X1 & 1268.274 & 398.1156 & 3.185693 & 0.0026 \\
X2 & 9086.860 & 3869.286 & 2.348459 & 0.0231 \\
X3 & 79.11202 & 52.80026 & 1.498326 & 0.1407 \\
X4 & -1402518. & 46301.68 & -30.29087 & 0.0000 \\
X5 & 293723.7 & 11481.34 & 25.58271 & 0.0000 \\
\hline \hline
\end{tabular}

\subsection{Pengaruh Cash Conversion cycle terhadap Earning before interest \& tax}

Variabel X1 menunjukkan nilai probabilitas 0,0026 nilai tersebut lebih kecil dari tingkat alpha yaitu 0,05 dan nilai koefisien 1268,274. Hal ini memberikan makna ketika Cash conversion cycle mengalami kenaikan maka Earning before interest \& tax akan meningkat. Tanda positif pada nilai koefisien menunjukkan pengaruh yang searah, yang artinya Earning before interest \& tax akan meningkat sebesar $1268,274 \%$ jika variabel Cash conversion cycle naik satu satuan dengan asumsi variabel lainnya konstan. Hasil ini memberi jawaban $\mathrm{H} 1$ diterima dan variabel ash conversion cycle berpengaruh positif dan signifikan terhadap Earning before interest \& tax.

\subsection{Current ratio terhadap Earning before interest \& tax}

Variabel X2 menunjukkan nilai probabilitas 0,0231 nilai tersebut lebih kecil dari tingkat alpha yaitu 0,05 dan nilai koefisien 9086,860. Hal ini memberikan makna ketika Current ratio mengalami kenaikan maka Earning before interest \& tax akan meningkat. Tanda positif pada nilai koefisien menunjukkan pengaruh yang searah, yang artinya Earning before interest \& tax akan meningkat sebesar 9086,860\% jika variabel Current ratio naik satu satuan dengan asumsi variabel lainnya konstan. Hasil ini memberi jawaban $\mathrm{H} 2$ diterima dan variabel Current ratio berpengaruh positif dan signifikan terhadap Earning before interest \& tax.

\subsection{Pengaruh Net working capital terhadap Earning before interest \& tax.}

Variabel X3 menunjukkan nilai probabilitas 0,1407 nilai tersebut lebih besar dari tingkat alpha yaitu 0,05 dan nilai koefisien 79,11202. Hal ini memberikan makna bahwa tinggi rendahnya Net working capital belum dapat mempegaruhi tinggi rendahnya Earning before interest \& tax. Artinya Net working capital yang baik atau meningkat belum berpotensi terhadap laba operasi sebuah perusahaan. Hasil ini memberi jawaban H3 diterima dan variabel Net working capital tidak berpengaruh signifikan terhadap Earning before interest \& tax

\subsection{Pengaruh Current Asset Turnover terhadap Earning before interest \& tax.}

Variabel X4 menunjukkan nilai probabilitas 0,0000 nilai tersebut lebih kecil dari tingkat alpha yaitu 0,05 dan nilai koefisien -1402518. Hal ini memberikan makna ketika Current Asset Turnover mengalami kenaikan maka Earning before interest \& tax akan menurun. Tanda negatif pada nilai koefisien menunjukkan pengaruh yang berlawanan arah, yang artinya Earning before interest \& tax akan menurun sebesar $-1402518 \%$ jika variabel Current asset turnover naik satu satuan dengan 
asumsi variabel lainnya konstan. Hasil ini memberi jawaban $\mathrm{H} 4$ ditolak dan variabel Current asset turnover berpengaruh negatif dan signifikan terhadap Earning before interest \& tax.

\subsection{Pengaruh Inventory turnover terhadap Earning before interest \& tax.}

Variabel X5 menunjukkan nilai probabilitas 0,0000 nilai tersebut lebih kecil dari tingkat alpha yaitu 0,05 dan nilai koefisien 293723,7. Hal ini memberikan makna ketika Inventory turnover mengalami kenaikan maka Earning before interest \& tax akan meningkat. Tanda positif pada nilai koefisien menunjukkan pengaruh yang searah, yang artinya Earning before interest \& tax akan meningkat sebesar $293723,7 \%$ jika variabel Inventory turnover naik satu satuan dengan asumsi variabel lainnya konstan. Hasil ini memberi jawaban H5 diterima dan variabel Inventory turnover berpengaruh positif dan signifikan terhadap Earning before interest \& tax.

\subsection{Kesimpulan}

\section{KESIMPULAN DAN SARAN}

Berdasarkan hasil penelitian ditarik kesimpulan sebagai berikut:

1. Cash conversion cycle berpengaruh terhadap Earning before interest \& tax. Hal ini menunjukkan bahwa ada pengaruh antara cash conversion cycle dengan laba operasi perusahaan, maka dapat dijelaskan bahwa semakin tinggi cash conversion cycle maka profitabilitas akan semakin meningkat juga.

2. Current Ratio berpengaruh terhadap Earning before interest \& tax artinya Semakin besar current ratio, semakin baik perusahaan itu karena akan semakin mampu merespon kebutuhan sehari-hari perusahaan, sehingga tujuan perusahaan untuk mendapatkan laba yang optimal dapat tercapai.

3. Net Working Capital Ratio (NWCR) tidak berpengaruh terhadap Earning before interest \& tax. Hal ini menunjukkan bahwa tidak pengaruh antara pengelolaan modal kerja dengan laba operasi perusahaan.

4. Current Asset Turnover (CAT) berpengaruh terhadap Earning before interest \& tax. artinya Besar kecilnya aktiva juga dipengaruhi oleh besar kecilnya aktiva likuid (kas dan sekuritas) yang dipertahankan oleh perusahaan.

5. Inventory turnover berpengaruh terhadap Earning before interest \& tax. Artinya Semakin tinggi tingkat perputaran persediaan, kemungkinan semakin besar perusahaan akan memperoleh keuntungan. Begitu pula sebaliknya, jika tingkat perputaran persediaannya rendah maka kemungkinan semakin kecil perusahaan akan memperoleh keuntungan

\subsection{Saran}

Berdasarkan kesimpulan dan keterbatasan penelitian maka saran yang dapat diajukan dalam penelitian ini adalah sebagai berikut :

1. Bagi Perusahaan

Perusahaan diharapkan untuk memperhatikan faktor-faktor Kinerja perusahaan melalui variabelvariabel yang berpengaruh positif dan signifikan terhadap Earning before interest \& tax yaitu cash conversion cycle, current ratio dan inventory turnover karena hal ini akan menarik investor untuk menanamkan modalnya pada perusahaan

\section{Bagi Investor}

Investor untuk menanamkan modalnya pada perusahaan. Harus memperhatikan faktor internal dari perusahaan yang bersangkutan. Dari hasil penelitian didapatkan bahwa investor perlu memperhatikan cash conversion cycl, current ratio dan inventory turnover dalam menentukan saham pilihan karena kedua variabel ini memiliki pengaruh positif dan signifikan terhadap Earning before interest \& tax yang artinya, Earning before interest \& tax akan meningkat seiring meningkatnya tiga variabel tersebut. Selain itu, Investor juga bisa melihat nilai Current Asset Turnover yang memiliki pengaruh negatif dan signifikan terhadap Earning before interest \& tax yang artinya, jika rasio tersebut naik maka Earning before interest \& tax pada perusahaan akan turun. 
3. Bagi Peneliti Selanjutnya

Bagi peniliti selanjutnya disarankan untuk menambahkan periode tahun penilitian, karena dalam penilitian ini hanya menggunakan 3 tahun sebagai periode penilitian. Selain itu dapat mengembangkan sektor industri yang akan diteliti. 


\section{DAFTAR PUSTAKA}

Akoto, R.K., Vitor, D.A., Angmor, P.L. (2013), Working capital management and profitability: Evidence from Ghanaian listed manufacturing firms. Journal of Economics and International Finance, 5(9), 373-379.

Ang, Robert. 1997. Buku Pintar Pasar Modal Indonesia (The Intelligent Guide to Indonesian Capital Market). Jakarta: Mediasoft Indonesia.

Dian Meriewaty, Astuti Yuli Setyani, 2005, Analisis Rasio Keuangan Terhadap Perubahan Kinerja Pada Perusahaan Di Industri Food And Beverages Yang Terdaftar Di BEJ, Jurnal Akuntansi Universitas Kristen DutaWacana, Vol.8:1-11

Deloof, Marc. 2003. Does Working Capital Management Affect Profitability of Belgian Firms? Journal of Business Finance \& Accounting, Vol. 30 No. 3, pp. 573-587.

Horne James C. Van dan John M.Wachowicz. 2009. Prinsip-Prinsip Manajemen Keuangan. alih bahasa Dewi Fitriasari dan Deny A.Kwary. Jakarta: Salemb Empat

Husnan, Suad. 2000. Manajemen Keuangan: Teori dan Penerapan (Keputusan Jangka Panjang). Yogyakarta: BPFE

Indriantoro, Nur, dan Bambang Supomo, 1999, Metodologi Penelitian dan Bisnis, Yogyakarta: BPFE Yogyakarta.

J.Fred Weston \& Thomas E. Copeland. 2007. Manajemen Keuangan jilid 1 dan 2. Jakarta : Binarupa Askara.

Kasmir (2012) Analisis Laporan Keuangan . Jakarta : PT Raja

Kaur, H.V., Singh, S. (2013), Managing efficiency and profitability through working capital: An empirical analysis of BSE 200 companies. Asian Journal of Business Management, 5(2), 197207

Napompech, K. (2012), Effects of working capital management on the profitability of Thai listed firms. International Journal of Trade, Economics and Finance, 3(3), 227-232.

Munawir. 2014. Analisa Laporan Keuangan. Edisi Keempat. Yogyakarta: Liberty

Raheman, A., Talat, A., Qayyum, A., Mahmood, A.B. (2010), Working capital management and corporate performance of manufacturing sector in Pakistan. International Research Journal of Finance and Economics, 47, 151-163

Sugiyono. 2012. Metode Penelitian Kuantitatif Kualitatif dan R\&D. Bandung:Alfabeta.

Syeh Ahsan Jamil 2015. The effect of working capital management efficiency on the operating performance of the industrial companies in oman, International Journal of Economics and Financial Issues, 897-904

Sen, M., Oruc, E. (2009), Relationship between efficiency level of working capital management and return on total assets in Ise. International Journal of Business and Management, 4(10), 109-114

Wibisono, C. Handoyo (1997) Manajemen Modal Kerja Edisi Ketiga, Yogyakarta: Universitas Atma Jaya Yogyakarta

Weston, J. Fred dan EF. Brigham. 1998. Dasar-dasar Manajemen Keuangan. Jakarta: Erlangga.

Weston J. Fred dan Eugene F. Brigham. 1991. Dasar-dasar Manajemen Keuangan, Jilid 2, Edisi Kesembilan, Terjemahan oleh Alfonsus Sirait, Jakarta: Erlangga 